\title{
TISSUE IRON AND THE RETICULO-ENDOTHELIAL SYSTEM IN RHEUMATOID ARTHRITIS
}

\author{
BY \\ D. L. GARDNER AND L. M. H. ROY* \\ Department of Pathology, University of Edinburgh, and Rheumatic Research Unit, Northern General Hospital, \\ Edinburgh
}

The cause of the normocytic hypochromic anaemia characteristic of rheumatoid arthritis remains unknown. Iron is absorbed normally from the gut (Roy, Alexander, and Duthie, 1955), but in an investigation of the iron content of the bone marrow (Richmond, Gardner, Roy, and Duthie, 1956) it was shown that stainable marrow iron was absent in nineteen of 61 cases and that there was no correlation between the presence or absence of iron in the marrow and the degree of anaemia.

It appeared likely that an unknown factor was interfering with the utilization of iron for the synthesis of haemoglobin. An increased tissue avidity for iron comparable to that postulated by Cartwright and Wintrobe (1952) as a cause of the anaemia of infection seemed a possible explanation. Earlier studies (Roy and others, 1955) had shown that saccharated oxide of iron injected intravenously was rapidly removed from the plasma of patients with rheumatoid arthritis. This observation supported the suggestion of the existence of a state of overactivity or of hyperplasia of the reticulo-endothelial system (Freireich, Ross, Bayles, Emerson, and Finch, 1957). Some evidence for such a hyperplasia was available from morphological studies (Sinclair and Cruickshank, 1956). Overactivity of the reticulo-endothelial system appeared to be a possible explanation for the paradox that iron found histologically in the bone marrow was not utilized in the synthesis of haemoglobin (Richmond and others, 1956).

On the basis of this hypothesis, it was postulated that in rheumatoid arthritis the organs comprising the reticulo-endothelial system might contain more iron than those of comparable subjects not suffering from this disease. The present investigation was planned to examine the validity of this hypothesis.

\footnotetext{
* Present address: Adelaide, Australia.
}

The analysis was conducted in parallel by histologicai and biochemical methods. The bone marrowo although part of the reticulo-endothelial system? was not examined since it had been studied pre $\overrightarrow{-}$ viously (Richmond and others, 1956).

\section{Material}

Samples of tissue from liver, spleen, lymph node $\stackrel{\mathbb{\Phi}}{\stackrel{-}{-}}$ suprarenal, and lung were obtained from 34 patients wh h rheumatoid arthritis who died in hospital and fre 43 patients not suffering from this disease.

Cases of Rheumatoid Arthritis (Tables I and II, oppo site).-In fifteen cases there was evidence that the patiento had not been given medicinal iron in any form. The organs of the reticulo-endothelial system of each wered examined histologically, but in only seven were chemica? analyses made. In the remaining eight cases, the availo able tissues were embedded in paraffin and extraction was found to interfere with the subsequent chemical estima tion of iron.

Material was available from nineteen further patientso to whom iron had been given by mouth, by intravenouse or by intramuscular injection, or in the form of whole blood by transfusion. The tissues of eighteen were examined histologically and of seventeen chemically.

Cases without Rheumatoid Arthritis (Tables I and II).Material was obtained from 43 patients. Chemical analyses were made on organs from each case, but in only 25 cases were all the organs examined histologically. This control material was divided into groups for comparison with the cases of rheumatoid arthritis.

\section{Methods}

Histological.-Tissue collected at necropsy was placed in clean glass containers with precautions to exclude contamination by environmental iron. Paraffin sections from this material were cut at $5-7 \mu$. and stained for iron ${ }^{-+}$ by a modification of the Prussian blue reaction (Richmond and others, 1956; Gardner, 1958). The 
TABLE I

TESTS CARRIED OUT IN CASES OF RHEUMATOID ARTHRITIS AND CONTROLS

\begin{tabular}{|c|c|c|c|c|c|c|c|c|c|c|c|}
\hline & \multirow{2}{*}{\multicolumn{5}{|c|}{ Source of Material }} & & & & & \multicolumn{2}{|c|}{ Analysis } \\
\hline & & & & & & & & & & \multirow{2}{*}{$\begin{array}{c}\text { Histological } \\
33\end{array}$} & \multirow{2}{*}{$\frac{\text { Chemical }}{24}$} \\
\hline \multirow{4}{*}{$\begin{array}{l}34 \text { Cases of } \\
\text { Rheumatoid Arthritis }\end{array}$} & Total No. of Cases & .. & . & . & .. & . & . & $\ldots$ & $\ldots$ & & \\
\hline & Males $\quad \ldots \quad \ldots$ & .. & $\begin{array}{l}\text { Total } \\
\text { Treated } \\
\text { Nor tre }\end{array}$ & $\begin{array}{l}\text { with I } \\
\text { ated w }\end{array}$ & ron & $\begin{array}{l}\ldots \\
\cdots\end{array}$ & $\begin{array}{l}\cdots \\
\cdots\end{array}$ & $\begin{array}{l}\cdots \\
\cdots\end{array}$ & \begin{tabular}{l|}
$\cdots$ \\
$\cdots$ \\
$\cdots$
\end{tabular} & $\begin{array}{r}10 \\
5 \\
5\end{array}$ & $\begin{array}{l}9 \\
6 \\
3\end{array}$ \\
\hline & Females .. & $\cdots$ & $\begin{array}{l}\text { Total } \\
\text { Treated } \\
\text { Nor tre }\end{array}$ & $\begin{array}{l}\text { with I } \\
\text { ated w }\end{array}$ & $\begin{array}{l}\text { ron } \\
\text { ith Iron }\end{array}$ & $\begin{array}{l}\cdots \\
\cdots \\
\cdots\end{array}$ & $\begin{array}{l}\cdots \\
\cdots \\
\cdots\end{array}$ & $\begin{array}{l}\cdots \\
\cdots \\
\cdots\end{array}$ & $\begin{array}{l}\ldots \\
\cdots \\
\cdots\end{array}$ & $\begin{array}{l}23 \\
13 \\
10\end{array}$ & $\begin{array}{r}15 \\
11 \\
4\end{array}$ \\
\hline & $\begin{array}{l}\text { Mean Age (yrs) } \ldots \\
\text { Range (yrs) }\end{array}$ & $\cdots$ & $\cdots$ & $\begin{array}{l}\cdots \\
\cdots\end{array}$ & $\begin{array}{l}\cdots \\
\cdots\end{array}$ & $\begin{array}{l}\cdots \\
\cdots\end{array}$ & $\cdots$ & $\begin{array}{l}\cdots \\
\cdots\end{array}$ & $\begin{array}{l}\cdots \\
\cdots\end{array}$ & $\begin{array}{c}58 \\
25-80\end{array}$ & $\begin{array}{c}60 \\
53-80\end{array}$ \\
\hline \multirow{5}{*}{43 Control Cases } & Total No. of Cases & $\cdots$ & $\cdots$ & $\cdots$ & $\cdots$ & - & $\cdots$ & $\cdots$ & $\ldots$ & 25 & 43 \\
\hline & $\begin{array}{l}\text { Group } 1(10) \\
\text { Sudden Death in }\end{array}$ & oung & Persons & $\cdots$ & . & $\cdots$ & $\begin{array}{l}\text { Male } \\
\text { Female }\end{array}$ & $\begin{array}{l}\cdots \\
\cdots\end{array}$ & $\begin{array}{l}\cdots \\
\cdots\end{array}$ & $\begin{array}{l}4 \\
3\end{array}$ & $\begin{array}{l}7 \\
3\end{array}$ \\
\hline & $\begin{array}{l}\text { Group } 2 \text { (16) } \\
\text { Rapid Death in } O\end{array}$ & ler $\mathbf{P}$ & ersons & . & . & & $\begin{array}{l}\text { Male } \\
\text { Female }\end{array}$ & $\begin{array}{l}\cdots \\
\cdots\end{array}$ & $\begin{array}{l}\cdots \\
\cdots\end{array}$ & $\begin{array}{l}4 \\
5\end{array}$ & $\begin{array}{l}8 \\
8\end{array}$ \\
\hline & $\begin{array}{l}\text { Group } 3(9) \\
\text { Comparable to } R\end{array}$ & euma & toid Artl & Iritis $\mathbf{P}$ & atients & & $\begin{array}{l}\text { Male } \\
\text { Female }\end{array}$ & $\begin{array}{l}. \\
\therefore\end{array}$ & $\cdots$ & 1 & $\begin{array}{l}6 \\
3\end{array}$ \\
\hline & $\begin{array}{l}\text { Group } 4(8) \\
\text { Excess Storage Ir }\end{array}$ & & $\cdots$ & $\cdots$ & $\cdots$ & $\cdots$ & $\begin{array}{l}\text { Male } \\
\text { Female }\end{array}$ & $\begin{array}{l}\cdots \\
\cdots\end{array}$ & $\begin{array}{l}\cdots \\
\cdots\end{array}$ & $\begin{array}{l}3 \\
4\end{array}$ & $\begin{array}{l}3 \\
5\end{array}$ \\
\hline
\end{tabular}

TABLE II

CAUSES OF DEATH IN CASES OF RHEUMATOID ARTHRITIS AND CONTROLS

\begin{tabular}{|c|c|c|c|}
\hline \multicolumn{2}{|c|}{ Group } & Causes of Death & Total Cases \\
\hline \multirow{2}{*}{ Rheumatoid Arthritis } & $\begin{array}{l}\text { Nor Given Iron or } \\
\text { Blood Transfusion }\end{array}$ & $\begin{array}{l}\text { Carcinoma of colon, } 3 \text {; chronic bronchitis, } 2 \text {; primary carcinoma } \\
\text { of liver, carcinoma of bronchus, leukaemia, meningitis, pneu- } \\
\text { monia, congestive cardiac failure, epilepsy, cervical dislocation, } \\
\text { vena caval thrombosis, and anaesthesia, one each }\end{array}$ & 15 \\
\hline & $\begin{array}{l}\text { Given Iron or } \\
\text { Blood Transfusion }\end{array}$ & $\begin{array}{l}\text { Bronchopneumonia or purulent bronchitis, 3; amyloidosis, 3; } \\
\text { carcinoma bronchus, carcinoma oesophagus, cor pulmonale, } \\
\text { septicaemia, pyelonephritis, systemic candidiasis, hypertension, } \\
\text { cardiac failure, cerebral infarction, aplastic anaemia, megalo- } \\
\text { blastic anaemia, gastric haemorrhage and steatorrhoea, and } \\
\text { perforated stomal ulcer, one each }\end{array}$ & 19 \\
\hline \multirow{4}{*}{ Controls } & Group 1 & $\begin{array}{l}\text { Trauma, 6; anaesthesia, } \mathrm{CO}_{2} \text { poisoning, methanol poisoning, and } \\
\text { subarachnoid haemorrhage, one each }\end{array}$ & 10 \\
\hline & Group 2 & $\begin{array}{l}\text { Myocardial infarction, } 5 \text {; cerebrovascular accident, } 4 \text {; pulmonary } \\
\text { embolism, } 3 \text {; cor pulmonale, } 2 \text {; malignant hypertension, and } \\
\text { fractured femur, one each }\end{array}$ & 16 \\
\hline & Group 3 & $\begin{array}{l}\text { Bronchopneumonia, 3; cerebral haemorrhage, intestinal obstruc- } \\
\text { tion, chronic cholecystitis, chronic duodenal ulcer, perforated } \\
\text { peptic ulcer, and myocardial ischaemia, one each }\end{array}$ & 9 \\
\hline & Group 4 & $\begin{array}{l}\text { Haemosiderosis, } 5 \text {; polycythaemia, } 2 \text {; injected intravenously with } \\
1 \text { g. iron immediately before death from cerebral vascular } \\
\text { disease, } 1\end{array}$ & 8 \\
\hline
\end{tabular}

amount of iron in representative microscopic fields was assessed visually and graded by a simple notation ranging from nil (no iron seen) to 5 (large amount of iron seen).

Sections were also stained with haematoxylin and eosin, and in a number of instances frozen sections were examined by the Weil-Davenport silver impregnation technique described by Marshall (1956). With this material the morphological state of the reticulo-endothelial system was assessed. In the liver, the distribution of iron between hepatic and Kupffer cells was noted. Prominence of Kupffer cells and excessive numbers of mononuclear cells in the portal tracts were recorded. In the spleen and lymph nodes, lymphoid follicular hyperplasia, reticulum cell hyperplasia, erythrophagocytosis, and excess of plasma cells were tabulated. In the lung, lymphoid hyperplasia and excessive numbers of mononuclear cells were noted, and in the suprarenal the state of the phagocytic sinus cells was studied. 
Chemical.--Material was collected at necropsy in clean jars and stored at $-10^{\circ} \mathrm{C}$. The method used for the chemical estimation of iron was essentially that of Ramsay and Campbell (1954). In a few instances fresh frozen tissue was not available and tissue which had been preserved in formalin for periods of up to 2 months was used (Kerr, 1957). Interference from haemoglobin was of significance only in tissues in which the concentration was very low. The method was shown to give a reasonable estimate of the non-haem iron concentration in all tissues with the exception of lung which was difficult to homogenize. Further difficulty was encountered where the lungs were those of city dwellers, on account of the presence of extraneous material of atmospheric origin.

\section{Morphological}

\section{Results}

\section{Iron CONTENT (Table III)}

Rheumatoid Arthritis.-In patients not given iron therapeutically, the livers contained more iron than in control groups 1,2 , and 3 , but less than in group 4 . The spleens also had a slightly higher mean iron content, but the amount of iron seen in lymph nodes, lungs, or suprarenals was so slight that differences between the groups were not defined.

Iron was distributed in the reticulo-endothelial system of cases of untreated rheumatoid arthritis in the same manner as in the comparable control groups 2 and 3 . Thus, in the spleen, iron was present as haemosiderin granules within the splenic pulp or sinusoids, or within macrophages lining the sinusoids. In twelve cases more was present within hepatic cells than within Kupffer cells.

The amount of iron found in the cases of rheumatoid arthritis treated with iron was greater than in? those not so treated, in each of the organs examined $\overrightarrow{\vec{F}}$ In five cases the Kupffer cells contained more ironf than the hepatic cells. In patients who had beenE given iron by injection, iron was found in the phago $\overline{\bar{n}}$. cytic sinus cells and histiocytes of the lymph nodes The iron content of the lung and suprarenal also conformed to this pattern, iron being present onlyes in the phagocytic cells.

Control Groups.-The amount of iron found histologically varied considerably between the foun groups. Iron was absent from the livers of casest in group 1, but was present in many of the livers of cases in groups 2 and 3 , being seen as smalp granules scattered diffusely in the hepatic cells ${ }_{i}^{\omega}$ Iron was present in the spleen in every case buf tended to be present in greater amounts in theo spleens of cases in groups 2 and 3 than in those of cases in group 1. It was most exceptional to finds stainable iron in the lymph nodes, lungs, or supra疋 renals unless, as in group 4, there was some inci $\stackrel{\vec{\Phi}}{3}$ dental clinical explanation for the local accumulation of iron-containing pigment.

\section{Histology (Table IV, opposite)}

The state of the cells in the five principal orgân of the reticular system (Marshall, 1956) is recorded in Table IV. There was evidence of frequent portaf round cell infiltration, of splenic and lymph-nodulañ follicular hyperplasia, and of an excessive number

TABLE III

TISSUE IRON CONTENT ASSESSED HISTOLOGICALLY AND CHEMICALLY

Histological Results: Arithmatic mean of arbitrary units

Chemical Results: mg. Fe/100 g. wet weight of tissue

\begin{tabular}{|c|c|c|c|c|c|c|c|c|}
\hline \multirow{2}{*}{\multicolumn{2}{|c|}{ Group }} & & \multirow{2}{*}{$\begin{array}{c}\text { No. } \\
\text { of } \\
\text { Cases }\end{array}$} & \multicolumn{4}{|c|}{ Tissue } & \\
\hline & & & & Liver & Spleen & Lymph Node & Lung & Suprarenal \\
\hline \multirow{4}{*}{ Control } & 1 & $\begin{array}{l}\text { Total } \\
\text { Histological } \\
\text { Chemical }\end{array}$ & $\begin{array}{r}10 \\
7 \\
10\end{array}$ & $\stackrel{0}{11 \cdot 1}$ & $\begin{array}{l}0 \cdot 55 \\
11 \cdot 5\end{array}$ & $\begin{array}{l}0 \\
1 \cdot 5\end{array}$ & $\begin{array}{l}0 \\
2 \cdot 5\end{array}$ & $\begin{array}{l}0 \\
3 \cdot 3\end{array}$ \\
\hline & 2 & $\begin{array}{l}\text { Total } \\
\text { Histological } \\
\text { Chemical }\end{array}$ & $\begin{array}{l}16 \\
10 \\
16\end{array}$ & $\begin{array}{l}0.25 \\
16 \cdot 9\end{array}$ & $\begin{array}{l}0 \cdot 56 \\
22 \cdot 2\end{array}$ & $\begin{array}{l}0 \cdot 4 \\
2 \cdot 9\end{array}$ & $\begin{array}{l}0 \cdot 2 \\
5 \cdot 5\end{array}$ & $\begin{array}{l}0 \\
3 \cdot 5\end{array}$ \\
\hline & 3 & $\begin{array}{l}\text { Total } \\
\text { Histological } \\
\text { Chemical }\end{array}$ & $\begin{array}{l}9 \\
2 \\
9\end{array}$ & $\begin{array}{r}0 \cdot 1 \\
17 \cdot 2\end{array}$ & $\begin{array}{r}0 \cdot 8 \\
32 \cdot 1\end{array}$ & $\begin{array}{l}\mathbf{0} \\
3 \cdot 3\end{array}$ & $\begin{array}{l}0 \cdot 1 \\
5 \cdot 4\end{array}$ & $\stackrel{0}{3 \cdot 5}$ \\
\hline & 4 & $\begin{array}{l}\text { Total } \\
\text { Histological } \\
\text { Chemical }\end{array}$ & $\begin{array}{l}8 \\
6 \\
8\end{array}$ & $\begin{array}{r}2 \cdot 3 \\
238 \cdot 1\end{array}$ & $\begin{array}{r}3 \cdot 0 \\
97 \cdot 6\end{array}$ & $\begin{array}{r}2 \cdot 0 \\
67 \cdot 4\end{array}$ & $\begin{array}{l}0.5 \\
6 \cdot 2\end{array}$ & $\begin{array}{l}0 \cdot 5 \\
4 \cdot 2\end{array}$ \\
\hline \multirow{2}{*}{ Rheumatoid Arthritis } & No Iron & $\begin{array}{l}\text { Histological } \\
\text { Chemical }\end{array}$ & $\begin{array}{r}15 \\
7 \\
\end{array}$ & $\begin{array}{r}0 \cdot 5 \\
20 \cdot 0 \\
\end{array}$ & $\begin{array}{r}1 \cdot 0 \\
21 \cdot 8 \\
\end{array}$ & $\begin{array}{l}0 \cdot 4 \\
4 \cdot 7 \\
\end{array}$ & $\begin{array}{l}0 \cdot 2 \\
3 \cdot 6\end{array}$ & $\begin{array}{l}0 \cdot 2 \\
3 \cdot 3 \\
\end{array}$ \\
\hline & Iron & $\begin{array}{l}\text { Histological } \\
\text { Chemical }\end{array}$ & $\begin{array}{l}18 \\
17\end{array}$ & $\begin{array}{r}1 \cdot 6 \\
70 \cdot 0\end{array}$ & $\begin{array}{r}2 \cdot 6 \\
127 \cdot 8\end{array}$ & $\begin{array}{r}1 \cdot 1 \\
21 \cdot 3\end{array}$ & $\begin{array}{l}1 \cdot 0 \\
8 \cdot 3\end{array}$ & $\begin{array}{r}0 \cdot 6 \\
11 \cdot 7\end{array}$ \\
\hline
\end{tabular}


TABLE IV

HISTOLOGICAL EXAMINATION OF ORGANS OF RETICULO-ENDOTHELIAL SYSTEM IN CASES OF RHEUMATOID ARTHRITIS

\begin{tabular}{|c|c|c|c|}
\hline Organ & $\begin{array}{l}\text { No. } \\
\text { Examined }\end{array}$ & Characteristic Recorded & $\begin{array}{l}\text { Number in } \\
\text { Which Found }\end{array}$ \\
\hline Liver & 34 & $\begin{array}{l}\text { Unusual prominence of Kupffer cells } \\
\text { Excessive round cell foci } \\
\text { Excess reticulum cells } \\
\text { Abnormal number of round cells in portal tracts }\end{array}$ & $\begin{array}{r}1 \\
6 \\
4 \\
18\end{array}$ \\
\hline Lymph Node & 20 & $\begin{array}{l}\text { Follicular hyperplasia } \\
\text { Sinus cell hyperplasia } \\
\text { Excess reticulum cells } \\
\text { Excess plasma cells }\end{array}$ & $\begin{array}{r}7 \\
9 \\
5 \\
10\end{array}$ \\
\hline Spleen & 34 & $\begin{array}{l}\text { Lymphoid follicular hyperplasia } \\
\text { Erythrophagocytosis } \\
\text { Excess reticulum cells } \\
\text { Excess sinus cells } \\
\text { Excess plasma cells }\end{array}$ & $\begin{array}{l}5 \\
0 \\
3 \\
7\end{array}$ \\
\hline Lungs & 34 & $\begin{array}{l}\text { Lymphoid hyperplasia } \\
\text { Excess reticulum cells }\end{array}$ & $\begin{array}{l}7 \\
1\end{array}$ \\
\hline Suprarenal & 25 & Sinus cell hyperplasia & 0 \\
\hline
\end{tabular}

of splenic and lymph-nodular plasma cells. However, it was difficult to define quantitatively any histological feature which indicated hyperplasia or hyperactivity of reticulo-endothelial cells. It was equally clear that the obvious possibility that there had been a hyperplasia of reticulo-endothelial cells without an alteration in their concentration could not be excluded.

\section{Chemical (Tables V, VI)}

Rheumatoid Arthritis.-The mean iron concentration in the tissues from seven patients with rheumatoid arthritis to whom iron had not been given therapeutically did not differ significantly from those for the entire control series. The number of tissue analyses was too small to allow of any attempt at correlation between iron concen- tration and age and sex, but a tendency for values to increase with age, and to a higher level in males, was apparent.

Comparison with control groups 2 and 3 revealed an increase of iron concentration in the lymph nodes in rheumatoid arthritis. The iron content of the spleen was also significantly greater than that of the spleen in control group 1, but was not different from that of either group 2 or 3 . The values for liver, lungs, and suprarenals from the rheumatoid cases did not differ from any control group.

Material was also available from seventeen patients with rheumatoid arthritis to whom iron had been given therapeutically. The results of the analyses of these tissues are compared with those of the untreated cases in Table VI (overleaf). Increased deposits of iron were found in all tissues examined, the increase being greatest in liver, spleen, and

TABLE V

MEAN TISSUE IRON CONTENT IN MATERIAL FROM PATIENTS WITH RHEUMATOID ARTHRITIS AND FROM CONTROLS

\begin{tabular}{|c|c|c|c|c|c|c|}
\hline \multirow{2}{*}{ Tissue } & & & \multicolumn{2}{|c|}{$\begin{array}{l}\text { Mean Values for Tissue Iron in Seven Patients with } \\
\text { Rheumatoid Arthritis NOT Treated with Iron }\end{array}$} & \multicolumn{2}{|c|}{$\begin{array}{l}\text { Mean Concentration of Tissue Iron in } \\
\text { Control Groups } 1 \text { to } 3\end{array}$} \\
\hline & & & $\begin{array}{l}\text { mg. Fe/100 g. Wet Weight } \\
\text { Tissue } \pm \text { S.D. }\end{array}$ & $\begin{array}{l}\text { No. of } \\
\text { Observations }\end{array}$ & $\begin{array}{l}\text { mg. Fe/100 g. Wet Weight } \\
\text { Tissue } \pm \text { S.D. }\end{array}$ & $\begin{array}{l}\text { No. of } \\
\text { Observations }\end{array}$ \\
\hline $\begin{array}{lc}\text { Liver } & \ldots \\
\text { Spleen } & \ldots \\
\text { Kidney } & \ldots \\
\text { Suprarenal } & \ldots \\
\text { Lymph Node } \\
\text { Cardiac } & \text { Muscle } \\
\text { Skeletal Muscle } & \text { Muin } \\
\text { Brain } & \ldots \\
\text { Pancreas } & \ldots \\
\text { Thyroid } & \ldots \\
\text { Lung } & \ldots \\
\text { Pituitary } & \ldots \\
\text { Ovary } & \ldots \\
\text { Testes } & \ldots \\
\text { Salivary } & \text { Gland }\end{array}$ & $\begin{array}{l}\cdots \\
\cdots \\
\cdots \\
\cdots \\
\cdots \\
\cdots \\
\cdots \\
\cdots \\
\cdots \\
\cdots \\
\cdots\end{array}$ & $\begin{array}{l}\cdots \\
\cdots \\
\cdots \\
\cdots \\
\cdots \\
\cdots \\
\cdots \\
\cdots \\
\cdots \\
\cdots \\
\cdots\end{array}$ & $\begin{array}{r}20.0 \pm 11.2 \\
21.8 \pm 10.3 \\
3.3 \pm \pm 1.5 \\
3.3 \pm 0.6 \\
4.7 \pm 3.1 \\
1.8 \pm 1.5 \\
1.0 \pm 0.4 \\
3.4 \pm 1.8 \\
1.5 \pm 0.7 \\
0.9 \pm 0.3 \\
3.6 \pm 1.2 \\
2.1 \pm- \\
0.6 \\
5.0 \\
1.2 \pm\end{array}$ & $\begin{array}{l}7 \\
7 \\
7 \\
7 \\
7 \\
4 \\
3 \\
5 \\
5 \\
5 \\
4 \\
1 \\
1 \\
2 \\
3\end{array}$ & 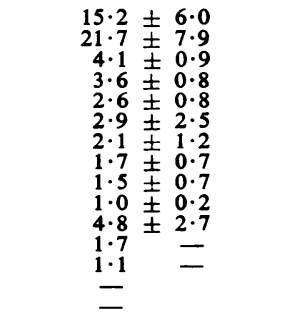 & $\begin{array}{r}35 \\
35 \\
33 \\
29 \\
19 \\
16 \\
14 \\
6 \\
15 \\
10 \\
19 \\
1 \\
1\end{array}$ \\
\hline
\end{tabular}


MEAN VALUES FOR TISSUE IRON

Expressed as mg. Fe/100 g. wet weight of tissue: \pm S.D.: $N=$ Number of Observations

\begin{tabular}{|c|c|c|c|c|c|c|c|c|c|c|c|c|c|}
\hline \multirow{2}{*}{\multicolumn{2}{|c|}{ Group }} & \multirow{3}{*}{ Sex } & \multirow{3}{*}{$\begin{array}{c}\text { Age } \\
(\mathrm{yrs})\end{array}$} & \multicolumn{8}{|c|}{ Tissue Iron } & & \\
\hline & & & & \multicolumn{2}{|l|}{ Liver } & \multicolumn{2}{|l|}{ Spleen } & \multicolumn{2}{|c|}{ Lymph Node } & \multicolumn{2}{|l|}{ Lung } & \multicolumn{2}{|c|}{ Suprarenal } \\
\hline & & & & $\mathrm{mg} / 100 \mathrm{~g}$ & $\mathbf{N}$ & $\mathrm{mg} / 100 \mathrm{~g}$. & $\mathbf{N}$ & mg./100 g. & $\mathbf{N}$ & mg./ $100 \mathrm{~g}$. & $\mathbf{N}$ & mg. $/ 100 \mathrm{~g}$. & $\mathbf{N} \bar{\sigma}$ \\
\hline \multirow{4}{*}{$\begin{array}{c}\text { Rheumatoid } \\
\text { Arthritis }\end{array}$} & \multirow{2}{*}{$\begin{array}{c}\text { Not Given } \\
\text { Fe }\end{array}$} & Total & 60 & $20 \cdot 0 \pm 11 \cdot 2$ & 7 & $21 \cdot 8 \pm 10 \cdot 3$ & 7 & $4 \cdot 7 \pm 3 \cdot 1$ & 7 & $3 \cdot 6 \pm 1 \cdot 2$ & 4 & $3 \cdot 3 \pm 0 \cdot 6$ & \\
\hline & & $\begin{array}{l}\text { Female } \\
\text { Male }\end{array}$ & $\begin{array}{l}63 \\
54\end{array}$ & $\begin{array}{l}15 \cdot 5 \\
26 \cdot 0\end{array}$ & $\begin{array}{l}4 \\
3\end{array}$ & $\begin{array}{l}17 \cdot 1 \\
28 \cdot 1\end{array}$ & $\begin{array}{l}4 \\
3\end{array}$ & $\begin{array}{l}3 \cdot 9 \\
5 \cdot 8\end{array}$ & $\begin{array}{l}4 \\
3\end{array}$ & $\begin{array}{l}2 \cdot 7 \\
4 \cdot 5\end{array}$ & $\begin{array}{l}2 \\
3\end{array}$ & $\begin{array}{l}3 \cdot 3 \\
3 \cdot 3\end{array}$ & $\begin{array}{l}0 \\
3 \\
\end{array}$ \\
\hline & \multirow{2}{*}{$\begin{array}{l}\text { Given Fe or } \\
\text { Transfusion }\end{array}$} & Total & 60 & $70 \cdot 0-$ & 17 & $127 \cdot 8-$ & 16 & $21 \cdot 3-$ & 16 & $8 \cdot 3-$ & 7 & $11 \cdot 7-$ & 13 \\
\hline & & $\begin{array}{l}\text { Female } \\
\text { Male }\end{array}$ & $\begin{array}{l}61 \\
60\end{array}$ & $\begin{array}{l}84 \cdot 7 \\
73 \cdot 1\end{array}$ & $\begin{array}{r}11 \\
6\end{array}$ & $\begin{array}{l}126.9 \\
130.9\end{array}$ & $\begin{array}{r}10 \\
6\end{array}$ & $\begin{array}{l}26 \cdot 5 \\
12 \cdot 7\end{array}$ & $\begin{array}{r}10 \\
6\end{array}$ & $\begin{array}{l}8 \cdot 4 \\
8 \cdot 3\end{array}$ & $\begin{array}{l}5 \\
2\end{array}$ & $\begin{array}{l}11 \cdot 8 \\
11 \cdot 6\end{array}$ & $\begin{array}{l}8 \vec{\omega} \\
5 \text { D }\end{array}$ \\
\hline \multirow{8}{*}{$\begin{array}{c}\text { Controls } \\
\text { grouped } \\
\text { according } \\
\text { to } \\
\text { Diagnosis }\end{array}$} & \multirow{2}{*}{1} & Total & 34 & $11 \cdot 1 \pm 6 \cdot 0$ & 10 & $11 \cdot 5 \pm 6 \cdot 8$ & 10 & $1 \cdot 7 \pm 0 \cdot 8$ & 6 & $2 \cdot 3 \pm 0 \cdot 8$ & 4 & $3 \cdot 8 \pm 1 \cdot 7$ & $10 \stackrel{\frac{\omega}{2}}{2}$ \\
\hline & & $\begin{array}{l}\text { Female } \\
\text { Male }\end{array}$ & $\begin{array}{l}43 \\
30\end{array}$ & $\begin{array}{r}8 \cdot 6 \\
12 \cdot 1\end{array}$ & $\begin{array}{l}3 \\
7\end{array}$ & $\begin{array}{r}9 \cdot 1 \\
12 \cdot 3\end{array}$ & $\begin{array}{l}3 \\
7\end{array}$ & $\begin{array}{l}1 \cdot 9 \\
1 \cdot 5\end{array}$ & $\begin{array}{l}3 \\
3\end{array}$ & $\begin{array}{l}1 \cdot 9 \\
2 \cdot 5\end{array}$ & $\begin{array}{l}1 \\
3\end{array}$ & $\begin{array}{l}4 \cdot 9 \\
3 \cdot 3\end{array}$ & 30 \\
\hline & \multirow{2}{*}{2} & Total & 66 & $16 \cdot 9 \pm 6 \cdot 7$ & 16 & $22 \cdot 2 \pm 11 \cdot 8$ & 16 & $2 \cdot 9 \pm 1 \cdot 2$ & 10 & $5 \cdot 5 \pm 2 \cdot 3$ & 8 & $3 \cdot 5 \pm 1 \cdot 1$ & 12 N \\
\hline & & $\begin{array}{l}\text { Female } \\
\text { Male }\end{array}$ & $\begin{array}{l}66 \\
66\end{array}$ & $\begin{array}{l}15 \cdot 5 \\
18 \cdot 3\end{array}$ & $\begin{array}{l}8 \\
8\end{array}$ & $\begin{array}{l}20 \cdot 8 \\
23 \cdot 7 \\
\end{array}$ & $\begin{array}{l}8 \\
8\end{array}$ & $\begin{array}{l}2 \cdot 7 \\
3 \cdot 1\end{array}$ & $\begin{array}{l}5 \\
5\end{array}$ & $\begin{array}{l}6 \cdot 1 \\
5 \cdot 2\end{array}$ & $\begin{array}{l}4 \\
4\end{array}$ & $\begin{array}{l}3 \cdot 2 \\
3 \cdot 9 \\
\end{array}$ & 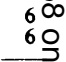 \\
\hline & \multirow{2}{*}{3} & Total & 66 & $17 \cdot 2 \pm 6 \cdot 5$ & 9 & $32 \cdot 1 \pm 8 \cdot 5$ & 9 & $3 \cdot 3 \pm 0 \cdot 4$ & 3 & $5 \cdot 4 \pm 2 \cdot 6$ & 7 & $3 \cdot 5 \pm 0 \cdot 9$ & $7 \rightarrow$ \\
\hline & & $\begin{array}{l}\text { Female } \\
\text { Male }\end{array}$ & $\begin{array}{l}70 \\
64\end{array}$ & $\begin{array}{l}14 \cdot 9 \\
17 \cdot 9\end{array}$ & 2 & $\begin{array}{l}29 \cdot 7 \\
32 \cdot 7\end{array}$ & $\begin{array}{l}2 \\
7\end{array}$ & $\begin{array}{l}2 \cdot 9 \\
3 \cdot 6\end{array}$ & $\begin{array}{l}1 \\
2\end{array}$ & $\begin{array}{l}4 \cdot 3 \\
5 \cdot 6\end{array}$ & $\begin{array}{l}1 \\
5\end{array}$ & $\begin{array}{l}3 \cdot 9 \\
3 \cdot 4\end{array}$ & 20 \\
\hline & 4 & Total & 53 & $238 \cdot 1-$ & 8 & $97 \cdot 6 \quad-$ & 8 & $67 \cdot 4-$ & 6 & $6 \cdot 2-$ & 3 & $4 \cdot 2-$ & $4 \frac{\text { D }}{3}$ \\
\hline & $1-3$ & Total & 51 & $15 \cdot 2 \pm 6 \cdot 0$ & 35 & $21 \cdot 7 \pm 7 \cdot 9$ & 35 & $2 \cdot 6 \pm 0 \cdot 8$ & 19 & $4 \cdot 8 \pm 2 \cdot 7$ & 19 & $3 \cdot 6 \pm 0 \cdot 8$ & \\
\hline
\end{tabular}

lymph nodes. Division of this group into those receiving iron orally, intravenously, or intramuscularly, and those receiving blood by transfusion revealed a difference in distribution of the additional iron. Whereas in both groups the hepatic iron content was increased by a factor of $3 \cdot 5$, the splenic iron content was increased by a factor of 5 in the former group and of 10 in the latter. In lymphatic tissues the opposite was found, the greatest increase being in the tissues from the patients to whom iron had been given orally, intravenously, or intramuscularly.

The mean weights of the liver and spleen from thirty fatal cases of rheumatoid arthritis were contrasted with those from thirty control cases of comparable age and sex (Table VII).

\section{TABLE VII}

COMPARISON BETWEEN MEAN WEIGHTS OF LIVER AND SPLEEN IN THIRTY CASES OF RHEUMATOID ARTHRITIS AND IN THIRTY CONTROL PATIENTS OF COMPARABLE AGE AND SEX DYING FROM SIMILAR CAUSES

\begin{tabular}{|c|c|c|c|}
\hline \multirow{2}{*}{ Series } & & \multicolumn{2}{|c|}{ Weight (g.) } \\
\hline & & Spleen & Liver \\
\hline $\begin{array}{l}\text { Rheumatoid Arthritis Patients } \\
\text { Control Cases . . . . . } \\
\text { Difference between Means } \\
\text { Standard Error of Difference }\end{array}$ & $\begin{array}{l}\cdots \\
\cdots \\
\cdots \\
\cdots\end{array}$ & $\begin{array}{l}224 \\
120 \\
104 \\
26 \cdot 1\end{array}$ & $\begin{array}{r}1,490 \\
1,435 \\
55 \\
86\end{array}$ \\
\hline
\end{tabular}

The results showed that the mean weights of liver in the two groups did not differ significan but that the mean weight of the spleen in the cases of rheumatoid arthritis was significantly greate than that in the control group.

On the basis of this analysis, and in view of the results of the chemical estimations, it is suggeste $\vec{b}$ tentatively that the spleen in rheumatoid arthritis ${ }^{3}$ may contain appreciably more iron than is norma in healthy individuals of the same age.

Control Groups.-Iron was found in high con $\frac{\text { o }}{2}$ centration in the liver and spleen, only small amountso being present in other tissues. Analyses of the results suggested that the concentration of iron in the tissues increased with advancing age, the correlations reaching greater significance in the case of the spleen than in that of the liver (spleen $\rightarrow$ $p=0.001$, liver: $p=0.02$ ). There was also tendency for more iron to be stored by males than by females. The mean iron content of liver andP spleen in the male group were 16.4 and $22.9 \mathrm{mg}$. N $100 \mathrm{~g}$. , and in the female group 13.7 and $19 \cdot \mathrm{N}_{\mathrm{W}}$ $\mathrm{mg} / 100 \mathrm{~g}$. respectively. This difference was em phasized by the fact that the male group was younger (mean age 52 years) than the female group (mean age 62 years).

The cases in groups 2 and 3 were originallyo chosen for comparison with the cases of rheumatoi $\overline{\mathrm{B}}$ 
arthritis. Analyses of the results in the individual groups revealed that the mean tissue iron concentrations increased from group 1, to group 2, to group 3. These differences reached the level of significance for liver of $p=0.02$, and for spleen of $p=0.001$ when groups 1 and 3 were compared. If, however, the mean ages of these two groups (34 and 66 years respectively) were taken into account, the apparently increased storage of iron with increasingly severe disease could be explained simply on the basis of advancing age.

As might be anticipated from previous reports of the iron content of tissues in iron storage diseases, the mean values obtained in group 4 were greatly increased by contrast with the other groups, irrespective of age.

\section{Discussion}

The storage of iron in body tissues in some human diseases has been sporadically investigated (Sheldon, 1935; Cappell, Hutchison, and Jowett, 1957). In health, the liver and the spleen are known to be the principal sites of iron storage and it is believed that 95 to 97 per cent. of such iron is available for haemoglobin synthesis (Finch, Hegsted, Kinney, Thomas, Rath, Haskins, Finch, and Fluharty, 1950). It seems reasonable to suppose that the liver and spleen in rheumatoid arthritis may contain a greater amount of iron than normal, since it is known that in this disease the red cells are hypochromic while the capacity to absorb iron from the small intestine is not impaired (Roy and others, 1955).

In the present investigation a comparison was made between the concentration of iron in the organs of the reticulo-endothelial system from cases of rheumatoid arthritis and that in those from cases selected to provide suitable control material. The spectrum of control cases was chosen to include young, healthy individuals, older persons dying unexpectedly, and persons of the same mean age as the group with rheumatoid arthritis dying from similar causes. As a result of this division it became clear that allowance must be made for the influence of age and sex on tissue iron concentration. It was shown that the concentration of iron in the liver and spleen of persons with rheumatoid arthritis was not significantly higher than that in controls of similar mean age dying from analogous causes. The iron concentration in lymph nodes, suprarenals, and lungs from cases of rheumatoid arthritis was also not significantly raised.

There is therefore no evidence to support the suggestion that the main iron storage organs in rheumatoid arthritis contain a greater concentration of iron than is usually the case. At the same time, histological examination of those tissues containing elements of the reticulo-endothelial system has provided no easily measurable evidence of reticuloendothelial hyperplasia or of reticulo-endothelial overactivity. However, there is an impression of hyperplasia of germinal follicles of the lymph nodes in many parts of the body and of the spleen. It is impossible to estimate the volume of lymphoid tissue in lymph nodes and throughout the viscera. Whether it is present in excess in rheumatoid arthritis is therefore not known, but measurement of weight has indicated that the spleen in rheumatoid arthritis is significantly larger than in control persons of the same age and sex. This suggests that the large spleen may contain a greater absolute amount of iron than usual and that the spleen may act as a reservoir for the iron absorbed, but not used in haemoglobin synthesis.

This interpretation must be viewed with some reserve. With the exception of the spleen, there is no suggestion of excessive storage of iron in rheumatoid arthritis. Low serum iron and the absence of stainable iron from the bone marrow may be explained by faulty absorption from the gut or excessive excretion of iron by the kidneys. The evidence at present available lends no support to these theories (Roy and others, 1955). It appears possible that further studies with labelled iron compounds may throw additional light on this problem. The present results may be regarded as providing an impetus to the extension of such observations.

\section{Summary}

Samples of liver, spleen, lymph node, lung, and suprarenal were collected at necropsy from 34 patients with rheumatoid arthritis who died in hospital. Similar samples were obtained from 43 control cases who died from other causes. The control cases were chosen in such a way that the influence of age and of sex on the tissue iron concentration could be assessed. The organs were examined histologically for iron by the Prussian blue reaction. Comparable tissue samples were analysed chemically for non-haem iron.

The concentration of iron in the liver, spleen, lungs, lymph nodes, and suprarenals in cases of rheumatoid arthritis not known to have received treatment with iron therapeutically or blood by transfusion was compared with that in the same organs of control cases. No difference in tissue iron concentration was found which could not be explained by invoking the demonstrated increase of storage iron with age, particularly in the male.

Histological examination of the organs of the reticulo-endothelial system revealed no satisfactory 
evidence for the nature of the hyperplasia or overactivity of this system which has been suggested as a likely explanation for the abnormal rapidity with which injected saccharated oxide of iron is removed from the plasma in patients with rheumatoid arthritis. Evidence of lymphoid hyperplasia was provided by the demonstration of significant splenic enlargement.

On the basis of this splenic enlargement it is tentatively suggested that the spleen may contain approximately twice as much iron in this disease as is normally the case. Proof of this suggestion must await chemical analyses of total splenic iron in further cases of rheumatoid arthritis.

The advice and encouragement of Prof. G. L. Montgomery and of Dr. J. J. R. Duthie are gratefully acknowledged.

During the period in which this work was performed, the Rheumatic Research Unit was in receipt of grants from the Medical Research Council, from the Nuffield Foundation, and from Boots Pure Drug Company.

\section{REFERENCES}

Cappell, D. F., Hutchison, H. E., and Jowett, M. (1957). J. Path. Bact., 74, 245.

Cartwright, G. E., and Wintrobe, M. M. (1952). Advanc. intern. Med., 5, 165.

Finch, C. A., Hegsted, M., Kinney, T. D., Thomas, E. D., Rath, C. E., Haskins, D., Finch, S., and Fluharty, R. G. (1950). Blood, 5, 983.

Freireich, E. J., Ross, J. F., Bayles, T. B., Emerson, C. P., and Finch, S. C. (1957). J. clin. Invest., 36, 1043.

Gardner, D. L. (1958). Stain Technol., 33, 295.

Kerr, L. M. H. (1957). Biochem. J., 67, 627.

Marshall, A. H. E. (1956). "An Outline of the Cytology and Pathology of the Reticular Tissue", p. 258. Oliver and Boyd, Edinburgh.

Ramsay, W. N. M., and Campbell, E. A. (1954). Biochem. J., 58, 313.

Richmond, J., Gardner, D. L., Roy, L. M. H., and Duthie, J. J. R. (1956). Ann. rheum. Dis., 15, 217.

Roy, L. M. H., Alexander, W. R. M., and Duthie, J. J. R. (1955). Ibid., 14, 63.

Sheldon, J. H. (1935). "Haemochromatosis." Oxford University Press, London.

Sinclair, R. J. G., and Cruickshank, B. (1956). Quart. J. Med., n.s. 25, 313.

Fer tissulaire et système réticulo-endothélial dans l'arthrite rhumatismale

\section{RÉSUMÉ}

On étudia les prélèvements de foie, rate, ganglions lymphatiques, poumon et surrénale, effectués à l'autopsie de 34 malades atteints d'arthrite rhumatismale décédés à l'hôpital. Des prélèvements similaires furent obtenus chez 43 témoins morts de diverses autres causes. Les témoins furent choisis de manière à permettre une étude comparée de l'influence de l'âge et du sexe sur le taux ferrique tissulaire. Histologiquement, le fer fue recherché dans les organes à l'aide du bleu de Prusse 3 Des échantillons comparables furent examinés chimique. ment pour déterminer le fer non-hématique.

Le taux de fer dans le foie, la rate, les poumons, les ganglions lymphatiques et dans les surrénales des cas? d'arthrite rhumatismale, n'ayant pas reçu, autant qu'ono sache, de thérapie martiale ou de transfusion sanguine $\frac{}{0}$ fut comparé à celui dans les mêmes organes des témoins $\overline{\bar{n}}$. On ne trouva dans les taux de fer tissulaire que desdifférences attribuables à l'emmagasinage augmenté de̊̊ ce métal avec l'âge, surtout chez les hommes.

Les examens histologiques des organes du systèmes réticulo-endothélial ne révélèrent rien qui puisse ex $\vec{\sigma}$ pliquer d'une manière satisfaisante la nature de l'hyper:plasie ou de l'activité exagérée de ce système, invoquées comme causes possibles de la vitesse anormale avecos laquelle l'oxyde saccharé de fer, injecté aux maladesô atteints d'arthrite rhumatismale, est éliminé de leup̄ plasma. L'hyperplasie lymphoïde fut prouvée par lơ fait que la rate était appréciablement augmentée de volume.

Cette augmentation du volume splénique nous faitr penser que dans cette maladie la rate peu bien conteniro deux fois plus de fer qu'une rate normale. Pour prouvers cette hypothèse on devra attendre les résultats del'analyse chimique du fer splénique total dans d'autrescs cas d'arthrite rhumatismale.

\section{Hierro tisular y el sistema reticulo-endotelial en la artritis reumatoide}

\section{Sumario}

Se recogieron muestras de hígado, bazo, gangl linfáticos, pulmón y suprarrenales en necropsias de $\frac{\mathcal{G}}{3} 40$ enfermos con artritis reumatoide fallecidos en hospitet Muestras similares se obtuvieron en 43 testigos que fallecieron de otras diversas causas. Los testigos fueron elegidos de tal forma que la influencia de la edad y eb̆

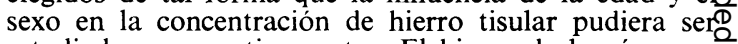
estudiada comparativamente. El hierro de los órganos se investigó histológicamente con la reacción del azul deō Prusia. Muestras comparables se examinaron químicamente para determinar el hierro no hemático.

La concentración de hierro en hígado, bazo, pulmones, ganglios linfáticos y suprarrenales en casos de artritisreumatoide, en los que se conocía no haber recibido terapéutica férrica, directa o por transfusión sanguínea se comparó con la hallada en los mismos órganos de los testigos. No se encontró ninguna diferencia en la concentración tisular de hierro que no fuese explicableo por el demostrado incremento de almacenaje de hierro con la edad, especialmente en el varón.

Exámenes histológicos de órganos del sistema reticulo-응 endotelial no produjeron datos para explicar satis- $D$ factoriamente la naturaleza de la hiperplasia o hiper-o actividad de dicho sistema, aducida como causa posible de la abnormal rapidez con que es eliminado del plasma el óxido sacarado de hierro inyectado en enfermos con artritis reumatoide. Prueba de la existencia de hiper-o plasia linfoidea fué encontrada en el significativo aumento del volumen del bazo.

Dicho aumento del volumen esplénico induce a pensar que el bazo pude contener, en casos de esta enfermedad, doble de la cantidad de hierro presente normalmente. Prueba de tal hipótesis debe esperar el análisis químico@ de la cantidad total de hierro esplénico en otros casos de artritis reumatoide. 